\title{
Kajian Produksi dan Penjualan Dendeng pada Beberapa Perusahaan di Kota Banda Aceh
}

(A Study on the Production and Selling of Dendeng At Various Corporations in Banda Aceh)

\author{
Cut Aida Fitri ${ }^{1}$, Didy Rachmadi ${ }^{1}$, Andri ${ }^{1}$ \\ ${ }^{1}$ Program Studi Peternakan, Fakultas Pertanian, Universitas Syiah Kuala
}

\begin{abstract}
ABSTRAK
Penelitian tentang hasil kajian produksi dan penjualan dendeng pada beberapa perusahaan di Kota Banda Acehini telah di lakukan dibeberapa perusahaan dendeng yang ada di kota Banda Aceh dari tanggal 28 September 2015 sampai dengan tanggal 28 Oktober 2015. Tujuan penelitian ini adalah untuk mengetahui bagaimana pengolahan manajemen usaha dendeng, juga untuk mengetahui berapa jumlah produk dendeng yang terjual perbulannya, dan bagaimana penentuan harga jual dendeng pada beberapa perusahaan dendeng di Kota Banda Aceh, Materi yang digunakan dalam penelitian terdiri 3 perusahaan dendeng yaitu: perusahaan dendeng Bungong Jaroe (setui), perusahaan dendeng Gunung Seulawah (Simpang Surabaya) dan perusahaan dendeng Blang Rakal (Kampung baru). Metode yang dilakukan penelitian ini adalah metode survei dengan analisis deskriptif. Parameter yang diamati dalam penelitian ini, yaitu pengolahan manajemen usaha dendeng sapi pada beberapa perusahaan dendeng di Kota Banda Aceh. Jumlah dendeng terjual perbulannya di Kota Banda Aceh.Harga jual sapi dendeng dibeberapa perusahan di Kota Banda Aceh dibandingkan dendeng luar Banda Aceh.Berdasakan hasil penelitian dapat disimpulkan bahwa jumlah dendeng terjual setiap bulannya, dapat dirincikan sekitar 1000 kilogram. Sedangkan mengenai penentuan harga dendeng sapi di Kota Banda Aceh mempunnyai 3 variasiharga, yaitu dendeng berkualitas tinggi, menengah dan kualitas tengah
\end{abstract}

Kunci: Daging Sapi, Kota Banda Aceh, Manajemen Usaha, Produksi Dendeng

\section{ABSTRACT}

A study on the production and selling of dendeng(beef jerky)at various corporations in Banda Aceh has been conducted at several dendengproducers in Banda Aceh from September 28, 2015 to October 28, 2015. The purposes of this study were to observe the business management of dendengventures, to know the amount of products sold monthly, and to observe how selling price were determined at several dendeng producers in Banda Aceh. The objects of this research were 3 dendeng outlets in Banda Aceh, which were: Bungong Jaroe (Seutui), Gunung Seulawah (Batoh), and Blang Rakal (Kampung Baru). Furthermore, survey method was used in this research and the data were analyzed descriptively. Meanwhile, the parameters observed were the business management, selling rate, and price. The results of the study elucidated that approximately 1000 kilograms dendengwere sold each month. The research findings also indicated that the price of dendengvaried based on their quality; super, medium, and low quality.

Keywords: Dendeng (beef jerky), dendeng productions, business management 


\section{PENDAHULUAN}

Kebutuhan akan daging sebagai salah satu sumber protein hewani terus meningkat seiring dengan meningkatnya laju populasi penduduk sekitar 1,5 per tahun. Selain itu, dengan semakin meningkatnya pengetahuan dan kesadaran masyarakat tentang pentingnya bahan makanan bergizi maka tidak cukup hanya dari segi kuantitas saja yang menjadi tolak ukur.Namun daging berkualitas juga menjadi bahan petimbangan bagi konsumen. Oleh karena itu berbagai cara pengawetan daging perlu dikembangkan.(Munarnis, 1982).

Lawrie (1995) menyatakan bahwa daging didefinisikan sebagai bagian dari hewan potong yang digunakan manusia sebagai bahan makanan, selain mempunyai penampakan yang menarik selera, juga merupakan sumber protein hewani berkualitas tinggi. Dalam daging terdapat asam amino esensial yg diperlukan tubuh, sehingga diharapkan selalu ada dalam makanan (Levie, 1970).

Menurut Lukman (2008) Penggolongan daging sapi/kerbau menurut kelasnya adalah yaitu golongan (kelas) I, meliputi daging bagian has dalam (fillet), tanjung (rump), has luar (sirloin), lemusir (cube roll), kelapa (inside), penutup (top side), pendasar + gandik (silver side). Golongan (kelas) II, meliputi daging bagian paha depan, sengkel (shank), daging paha depan (chuck), daging iga (rib meat), daging punuk (Blade). Golongan (kelas) III, meliputi daging lainnya yang tidak termasuk golongan I dan II, yaitu samcan (flank), sandung lamur (brisket ). Dijelaskan pula bahwa faktor kualitas daging yang dimakan meliputi warna, keempukan, tekstur, flavor (cita rasa), aroma (bau), dan kesan jus daging (juiciness) Soeparno (2005).

Soeparno (2005) menjelaskan lebih lanjut bahwa keadaan fisik daging dapat dikelompokkan menjadi (1) daging segar yang dilayukan atau tanpa pelayuan, (2) daging yang dilayukan kemudian didinginkan (daging dingin), (3) daging yang dilayukan, didinginkan, kemudian dibekukan (daging beku), (4) daging masak, (5) daging asap dan (6) daging olahan.

Kini seiring dengan kemajuan zaman, tidaklah sulit untuk mendapatkan daging dan produk olahannya karena kini sudah tersedia dipasar tradisional maupun dipasar swalyan.Begitu juga dengan variasi produk olahannya yang banyak tersedia dalam berbagai bentuk (Nursiam, 2010).

\section{METODE PENELITIAN}

Penelitian ini dilakukan langsung padabeberapa perusahan dendeng yang ada di kota Banda Aceh yang meliputi perusahaan dendeng Bungong Jaroe (Setui), perusahaan dendeng Gunung Seulawah (Simpang Surabaya), dan perusahaan dendeng Blang Rakal (Kampung Baru). Penelitian berlangsung dari tanggal 28 September sampai dengan 28 Oktober 2015.

\section{MATERI DAN METODE}

Materi yang digunakan dalam penelitianini terdiri dari 3 perusahaan dendeng, yaitu: perusahaan dendeng Bungong Jaroe (Setui), perusahaan dendeng sapi Gunung Seulawah (Simpang Surabaya), dan perusahaan dendeng sapi Blang Rakal (Kampung Baru).

\section{Metode Penelitian}

Metode yang dilakukan pada penelitian ini adalah metode survei dengan analisis deskriptif. Data diperoleh dengan menggunakan kuisioner yang diajukan pada para pengusaha dan pegawai di beberapa perusahaan dendeng yang ada di kota Banda Aceh. Sedangkan data dilakukan dengan menggunakan tabulasi dan presentase. 


\section{Parameter Penelitian}

Parameter yang diamati dalam penelitian ini, yaitu :

1.Pengelolaan manajemen usaha dendeng sapi pada beberapa perusahaan dendeng di Kota Banda Aceh.

2. Jumlah dendeng yang terjual perbulannya di Kota Banda Aceh.

3. Harga jual dendeng sapi pada beberapa perusahaan dendeng di Kota Banda Aceh di banding dendeng luar Aceh.

\section{HASIL DAN PEMBAHASAN}

\subsection{Karakteristik Sampel}

Karateristik sampel adalah gambaran umum atau keadaan dari sampel yang berkaitan serta mempengaruhi aktivitas yang dilakukan di daerah penelitian. Dalam penelitian ini karatristik usaha dendeng yang dimaksud yaitu meliputi tahun berdiri perusahaan, usia karyawan, pendidikan terakhir karyawan dan lama bekerja sebagai karyawan.

Tabel 2. Nama, Alamat, Tahun dan Jumlah Tahun Berdiri Perusahaan

\begin{tabular}{llll}
\hline \multicolumn{1}{l}{ NoNama PerusahaanAlamat PerusahaanTahun BerdiriJumlah Tahun } & \\
\hline $1 \quad$ Dendeng Gunung Seulawah & Simpang Surabaya & 1978 & 38 \\
2Blang Rakal & Kampung Baru & 1996 & 20 \\
3Bungong Jaroe & Setui & 2008 & 8 \\
\hline
\end{tabular}

Sumber : Data Primer (2015)

Berdasarkan Tebel 2 di atas, menunjukkan bahwa perusahaan Dendeng Gunung Seulawah didirikan pada 1978, Blang Rakal 1996 dan Bungong Jaroe 2008. Dari ketiga perusahaan tersebut jelas bahwa perusahaan Dendeng Gunung Seulawah paling tua umurnya, yaitu 38 dibanding dengan dua perusahaan tersebut.Sedangkan untuk perusahaan yang baru terjun kedalam bisnis dendeng ialah perusahaan Bungong Jaroe yang mana usahanya baru berjalan 8 tahun.

Untuk data usiakaryawan, pendidikan terakhir karyawan dan lama bekerja sebagai karyawan peneliti mengambil 20 sampel dari ketiga perusahan yang tertera pada table 2diatas.

\subsubsection{Lama Bekerja Sebagai Karyawan}

Lamanya suatu karyawan berkerja dalam suatu perusahaan maka dapat dikatagorikan perusahan tersebut sangat baik manajemennya,karena bila perusahan tersebut bergontaganti karyawan maka kinerja dalam usaha itu akan terhambat.

Tabel 3. Lama Responden Bekerja Sebagai Karyawan pada Perusahaan Dendeng

\begin{tabular}{lccc}
\hline No & Lama Menjadi Karyawan & Jumlah (Jiwa) & Presentase (\%) \\
\hline 1 & Kurang dari 1 Tahun & 3 & 15 \\
2 & 1-3 Tahun & 5 & 25 \\
3 & Lebih dari 3 Tahun & 12 & 60 \\
\hline Jumlah & & 20 & 100 \\
\hline
\end{tabular}

Sumber : Data Primer (2015)

Berdasarkan Tabel 3 di atas, menunjukkan bahwa lama responden bekerja sebagai karyawan pada perusahaan dendeng tersebut 3 tahun lebih berjumlah 60 persen. Hal ini memperlihatkan bahwa ketiga perusahan ini sangat baik dalam manajemen usahanya, karena $60 \%$ dari karyawannya tersebut sudah lama berkerja diperusahan tersebut. Sedangkan untuk 
40\% lagi karyawan tersebut di persiapkan untuk penerus dari karyawan lama yang mungkin nantiknya kinerjanya sudah kurang baik karena disebabkan oleh faktor usia.

\subsection{Sistem Manajemen Pengolahan Dendeng}

\subsubsection{Asal Daging Sapi yang Dibuat Menjadi Dendeng}

\subsection{2.}

Dalam proses pembuatan dendeng, daging sapi merupakan bahan baku utama dalam pembuatannya. Berikut ini peneliti akan menjelaskan asal daging sapi yang digunakan oleh pelaku usaha dendeng sapi tersebut sebagaimana yang tertera dalam Tabel 4 di bawah ini.

\subsubsection{Penjualan Perbulan}

Dari 3 perusahaan dendeng di Kota Banda Aceh, bisa dikatakan semuanya laris dan banyak pembelinya, baik dengan cara langsung pada perusahaannya atau dengan membelinya di swalayan dan tempat pemasaran lainnya. Lebih jelasnya dapat dilihat pada tabel berikut ini.

Tabel 5. Jumlah Dendeng yang Terjual Perbulannya

\begin{tabular}{lllc}
\hline No & Nama Perusahaan & Alamat Perusahaan & JumlahDendeng \\
\hline 1 & Gunung Seulawah & Simpang Surabaya & $800 \mathrm{Kg}$ \\
2 & Blang Rakal & Kampung Baru & $150 \mathrm{Kg}$ \\
3 & Bungong Jaroe & Setui & $50 \mathrm{Kg}$ \\
\hline Jumlah & & $1000 \mathrm{Kg}$ \\
\hline
\end{tabular}

Sumber : Data Primer (2015)

Pada tabel 5 di atas menunjukkan bahwa, keseluruhan dendeng yang terjual perbulannya sejumlah 2000 kilogram, atau 2ton.hal ini sangat logis, karena Banda Aceh selalu dikunjungi para wisata dari belahan dunia.

\subsubsection{Harga Dendeng Menurut Kualitas}

Setiap perusahaan yang menghasilkan produk yang akan dijual kepada orang lain, tentu mempunyai harga yang standar atau harga yang sudah ditetapkan oleh perusahaan itu sendiri, begitu dengan ketiga perusahaan tersebut mempunyai harga tetap pada produk yang dihasilkan. Tentu ketiga perusahaan ini mempunyai harga yang berbeda-beda, mulai dari dendeng yang berkualitas tinggi dan rendah. Dalam tabel ini akan dijelaskan secara rincian.

Tabel 6. Rincian Harga Dendeng yang Berkualitas Tinggi Per Kilogram

\begin{tabular}{llc}
\hline No & Nama Perusahaan & Kualitas Tinggi (Rp) \\
\hline 1 & Dendeng Gunung Seulawah & 220.000 \\
2 & Blang Rakal & 260.000 \\
3 & Bungong Jaroe & 180.000 \\
\hline
\end{tabular}

Sumber : Data Primer (2015)

Pada Tabel 6 di atas menunjukkan bahwa harga dendeng pada 3 perusahaan di Banda Aceh mempunyai produk dendeng yang berkualitas tinggi.Dendeng yang berkualitas tinggi 
mempunyai harga yang berbeda-beda, namun harga yang paling mahal adalah perusahaan dendeng Blang Rakal, yaitu 260.000 perkilogram

\begin{tabular}{llc}
\hline No & Nama Perusahaan & Kualitas Menengah (Rp) \\
\hline 1 & Dendeng Gunung Seulawah & 180.000 \\
2 & Blang Rakal & 190.000 \\
3 & Bungong Jaroe & 170.000 \\
\hline
\end{tabular}

Tabel7 . Harga Dendeng Kualitas Menengah

Sumber : Data Primer (2015)

Pada tabel 7 di atas menunjukkan bahwa harga dendeng pada 3 perusahaan di Banda Aceh menunjukkan harga yang berbeda-beda. Dendeng kualitas menengah yang paling mahal adalah perusahaan dendeng Blang Rakal yaitu Rp 190.000 perkilogram, sedangkan dendeng berkualitas menengah yang paling murah adalah perusahaan dendeng Bungong Jaroe yaitu Rp 170.000 perkilogram

\subsubsection{Pendapatan Usaha Dendeng}

Untuk merincikannya pendapatan akan usaha dendeng sapi tentu diperlukan informasi yang akurat agar dapat disimpulkan. Untuk itu dapat dilihat pada tabel di bawah ini.

Tabel 8.Nama, Pendapatan Ketiga Perusahaan Perminggu dan Perbulan.

\begin{tabular}{llcl}
\hline No & $\begin{array}{l}\text { Nama } \\
\text { Perusahaan }\end{array}$ & $\begin{array}{l}\text { Pendapatan } \\
\text { Perminggu }\end{array}$ & $\begin{array}{l}\text { Pendapatan } \\
\text { perbulan }\end{array}$ \\
\hline 1 & Dendeng Gunung Seulawah & $\operatorname{Rp~} 8.500 .000$ & $\operatorname{Rp~} 34.000 .000$ \\
2 & Blang Rakal & $\operatorname{Rp~} 875.000$ & $\operatorname{Rp~} 3.500 .000$ \\
3 & Bungong Jaroe & $\operatorname{Rp~} 1.575 .000$ & $\operatorname{Rp~} 6.300 .000$ \\
\hline
\end{tabular}

Sumber : Data Primer (2015)

Pada Tabel 8 di atas menunjukkan bahwa pendapatan setiap perusahaan berbeda-beda, sesuai dengan jumlah dendeng yang dipasarkan.Sedangkan pendapatan tersebut bisa dikatakan pendapatan bersih setiap minggu dan bulan.Maka hal yang logis kenapa perusahaan-perusahaan itu dapat bertahan sampai sekarang ini, sebab pendapatannya dapat memuaskan pemilik perusahaan itu sendiri.

Dari penjelasan di atas dapat disimpulkan bahwa perusahaan dendeng di Kota Banda Aceh selalu saja laris dan berkembang, dapat dilihat berdasarkan dari tahun berdirinya sudah melebihi dari lima tahun, itu menunjukkan bahwa perusahaan tersebut, mendapatkan untung yang begitu besar.

Oleh karenanya, perusahaan-perusahaan tersebut mampu bertahan sejak berdirinya sampai sekrang ini, dinbanding dengan perusahaan dendeng di tempat lain, yang tidak mampu bertahan sampai puluhan tahun.

\section{PENUTUP}

\subsection{Kesimpulan}

Berdasarkan hasil penelitian dapat disimpulkan bahwa jumlah dendeng yang terjual setiap bulannya, dapat dirincikan sekitar 1000 kilo gram. Hal ini sangat logis, dikarenakan Banda Aceh merupakan Ibukota Provinsi Aceh, tentu para wisata sangat banyak yang datang, mulai dari lokal maupun luar daerah, mereka berkunjung dan membeli dendeng sapi sebagai oleh-oleh dari Kota Banda Aceh. Sedangkan mengenai penentuan harga dendeng sapi di Kota 
Banda Aceh mempunyai 3 variasai harga, yaitu dendeng berkualitas tinggi, menengah dan kualitas rendah.

\subsection{Saran}

Adapun saran peneliti kepada perusahaan dendeng sapi yang ada beroperasi di Kota Banda Aceh ini agar menetapkan harga standar, supaya para pembeli dapat mengetahuinya.Ini dapat menambah kepuasan para pelanggan ketika mereka sudah melihat label harga yang telah ditentukan, serta mempromosikan dendeng sapi ini sebagai salah satu oleh-oleh khas Banda Aceh.

\section{DAFTAR PUSTAKA}

Anonim, 2009. Pembuatan Dendeng. Jurusan Teknologi Pangan dan Gizi Institut Pertanian Bogor, Bogor.

Astawan, M. 2004. Dapatkan Protein dari Dendeng.http//www.gizi.net/dapatkan proteindendeng/index.html. Diakses April 2016.

Bailey, M.E. 1998. Maillard Reaction and Meat Flavour Development. Dalam: F. Shahidi (Ed), Flavour or Meat Product and Seafood Second Edition. Blackie Academic and Profesional. New York.

Buckle, K. A., R. A. Edwards, G. H. Fleet dan M. Wooton. 1987. Ilmu Pangan. Terjemahan : H. Purnomo dan Adiono. Universitas Indonesia Press, Jakarta.

Lukman, D.W., 2008. Daging dan produk olahannya.http://higiene pangan.blogspot.com.Diakses : Februari 2010.

Purnomo, H.,1996. Dasar-dasar Pengolahan dan Pengawetan Daging. PT Grasindo, Jakarta

Munarnis E. 1982. Pengolahan Daging. CV. Yasaguna, Jakarta.

Soeparno.2005. Ilmu dan Teknologi Daging. Gajah Mada University Press, Yogyakarta. 